\title{
Subsurface structure of the Myojin Knoll pumiceous volcano obtained from multichannel seismic reflection data
}

\author{
Tetsuro Tsuru ${ }^{1 *}$, Ayumi Okuda ${ }^{2 \dagger}$, Tetsuo No ${ }^{1}$, Yoshiyuki Kaneda ${ }^{1}$, and Kensaku Tamaki ${ }^{2}$ \\ ${ }^{1}$ Japan Agency for Marine-Earth Science and Technology (JAMSTEC), Showa-machi 3173-25, Kanazawa-ku, Yokohama 236-0001, Japan \\ ${ }^{2}$ University of Tokyo, 7-3-1 Hongo, Bunkyo-ku, Tokyo 113-0032, Japan
}

(Received November 21, 2007; Revised March 10, 2008; Accepted March 11, 2008; Online published August 4, 2008)

\begin{abstract}
The Myojin Knoll is a submarine volcano that has a classically beautiful conical-shaped silicic caldera whose surface is covered by pumice. To determine the tectonic structure inside the caldera wall and beneath the caldera floor of this pumicious submarine volcano, we carried out a structural interpretation study using newly collected deep-penetrating multichannel seismic (MCS) reflection data. We also conducted a detailed velocity analysis of the MCS data, which facilitated the interpretation study. The results demonstrate that approximately $90 \%$ of the caldera wall is composed of pumiceous volcanic breccia. This finding supports those of previous researchers who, based on seafloor observations, single-channel seismic reflection, and gravity and geomagnetic data, concluded the Myojin Knoll is a knoll having a pumiceous caldera wall underlain by a pre-caldera rhyolitic stratovolcano edifice. We also determined a down-warping reflector approximately $800 \mathrm{~m}$ beneath the caldera floor. A seismic unit immediately above the reflector has a higher $P$-wave velocity than the pumice units and shows a chaotic seismic reflection pattern. We interpreted the reflector to be the bottom of a possible shallow magma chamber where the magma would undergo repeated expansion and contraction as a result of recurrent eruption activities.
\end{abstract}

Key words: Myojin Knoll, caldera, pumice, seismic reflection, magma.

\section{Introduction}

The tectonic evolution of the Izu-Ogasawara (Bonin) Arc located at the eastern rim of the Philippine Sea has been well studied by geological and geophysical observations (e.g., Honza and Tamaki, 1985; Suyehiro et al., 1996; Takahashi et al., 2006), while much of formation histories of submarine volcanoes on the volcanic front of the Arc remain unexplained. Among those, the Myojin Knoll, which is located $32^{\circ} 06^{\prime} \mathrm{N}, 139^{\circ} 51^{\prime} \mathrm{W}$, is known as a submarine volcano that has a classically beautiful conical-shaped caldera (basal diameter: 15-22 km; rim diameter: 5-7 km (Yuasa et al., 1991; Naka et al., 1995)). There are two submarine volcanoes, the Myojinsho Knoll and the Bayonnaise Knoll, near the Myojin Knoll, which implies that magma activity in this area has been considerably high. The activity of the submarine volcanoes in the northern Izu-Ogasawara volcanic arc is characterized by bimodal magmatism with basalt and dacite-rhyolite (e.g., Tamura and Tatsumi, 2002), with the Myojin, Myojinsho and Bayonnaise knolls all belonging to the silicic type of volcanoes.

Since the 1990s, many submarine hydrothermal vents have been discovered in the northern Izu-Ogasawara region. Among these, a large Kuroko-type polymetallic sulfide de-

*Current address: Cosmo Energy Exploration \& Development Ltd, 2 2-24, Higashishinagawa, Shinagawa-ku, Tokyo 140-000, Japan.

${ }^{\dagger}$ Current address: Keisen Junior/Senior High School, 5-8-1, Funabashi, Setagaya-ku, Tokyo 156-0055, Japan.

Copyright (c) The Society of Geomagnetism and Earth, Planetary and Space Sciences (SGEPSS); The Seismological Society of Japan; The Volcanological Society of Japan; The Geodetic Society of Japan; The Japanese Society for Planetary Sciences; TERRAPUB. position on the southeast caldera floor of the Myojin Knoll (Iizasa et al., 1999) was the largest discovery, initiating interest in the availability of natural resources on silicic volcanoes in the northern Izu-Ogasawara Arc. Consequently, a tectonic study of the Myojin Knoll is important in not to advance our knowledge of volcanology but also in terms of natural resource exploration.

Current bathymetry data and the results of diving surveys by the manned submersible Shinkai 2000 of the Japan Agency for Marine-Earth Science and Technology (JAMSTEC) indicate that the surface of the caldera wall of the Myojin Knoll is covered by rhyolite pumice (Naka et al., 1995; Yuasa, 1995; Fiske et al., 1995, 2001). The results of previous studies using single-channel seismic (SCS) reflection data (e.g., Yuasa et al., 1991; Murakami, 1997; Yuasa and Kano, 2003) indicated the presence of stratified deposits within the caldera wall. Moreover, the Knoll is characterized by a weak positive gravity anomaly and an ultraweak magnetic anomaly (e.g., Murakami and Ishihara, 1985; Ishihara and Yamazaki, 1991). Based on these observations, many researchers have proposed formation histories of the Myojin Knoll caldera. For example, Yuasa et al. (1991) proposed that the Myojin Knoll caldera is a huge submarine pumice cone, and Yuasa (1995) confirmed that explosive eruptions ejecting pumice formed a knolllike a pyroclastic cone with a caldera-like depression at the Knoll. Murakami (1997) supported this pumiceous caldera concept based on the results of geophysical studies, while mentioning the possibility of explosion caldera. Fiske et al. (2001) presented a well thought-out formation history of the Myojin Knoll volcano, which includes a caldera-collapse 


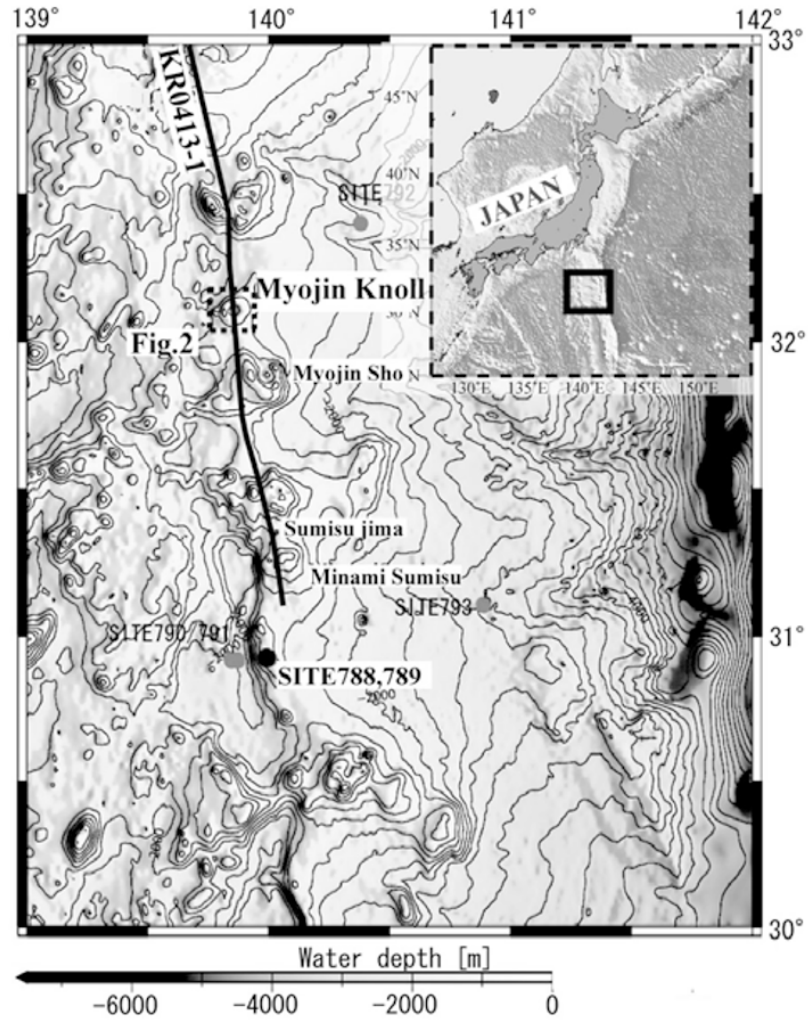

Fig. 1. Study area and Myojin Knoll caldera. Solid line represents an MCS reflection survey track passing over the volcanic front of the northern Izu-Ogasawara arc.

structure after an eruption ejecting an enormous amount of pumice. In their observations, a total thickness of preand syn-caldera pumice exceeds $500 \mathrm{~m}$ at the caldera wall. Given the relief of the Myojin Knoll caldera (500-900 m), we would suggest that the Myojin Knoll is a pumiceous volcano. However, the mode of formation of the caldera is still unknown.

In this paper, we demonstrate a tectonic structure of the Myojin Knoll from newly collected deep-penetrating multichannel seismic (MCS) data and its velocity analysis, verify the presence of stratified pumice layers within the caldera wall, and discuss the mode of caldera formation. Based on our results and those of earlier investigations, we suggest the existence of a shallow magma chamber that was formed in the period of eruptions beneath the caldera floor.

\section{Seismic Reflection Surveys}

As part of an integrated crustal study aimed at gaining an understanding of the evolution of the Izu-Ogasawara Arc, the KR04-13 survey cruise was conducted by R/V Kairei of JAMSTEC in 2004. During the cruise, MCS reflection data were collected along the present volcanic front of the northern Izu-Ogasawara Arc (Tsuru et al., 2005). As shown in Fig. 1, a seismic line, KR0413-1, passes over the caldera of the Myojin Knoll from the north to the south. A 200-1 airgun array that radiates larger seismic energy with lower frequency than the conventional one was used to collect deep-penetrating MCS data in the volcanic area. A 5-kmlong 204-channel streamer cable was used as a receiver; this length enabled velocity structures both within the caldera

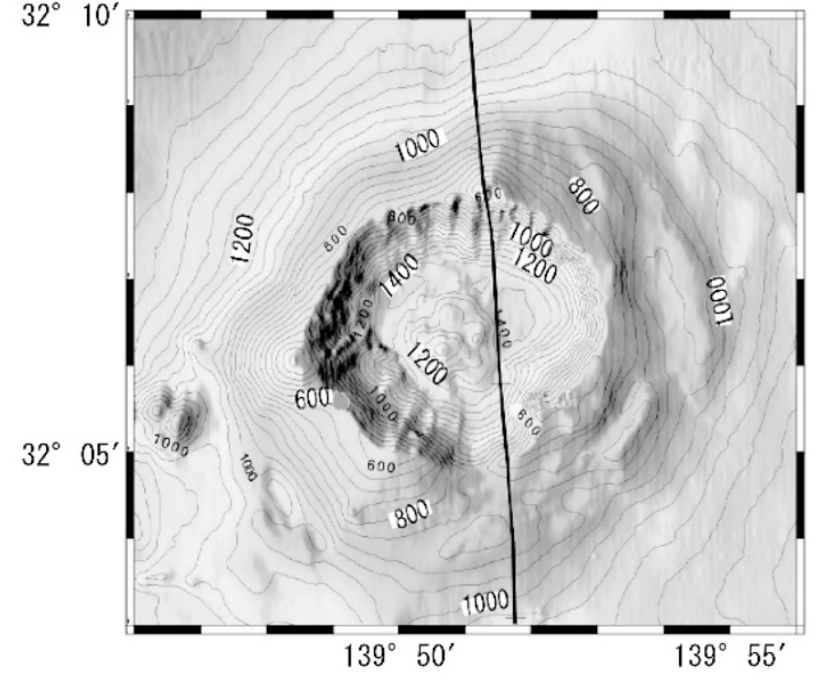

Fig. 2. Bathymetry of Myojin Knoll. Line KR0413-1 was planned so as to pass over the caldera from north to south, passing approximately $1 \mathrm{~km}$ east of the central cone.

wall as well as beneath the caldera floor to be analyzed. Shot and group spacing were 50 and $25 \mathrm{~m}$, respectively. The sampling rate was $4 \mathrm{~ms}$ and the total record length, $13.5 \mathrm{~s}$.

\section{Geologic Structure of Myojin Knoll}

The Myojin Knoll has a sculpturesque outer rim, which is composed of three peaks. The highest peak, which has a water depth of $336 \mathrm{~m}$, is located on the west rim of the caldera (Fig. 2). The central cone has three to four highs and is disproportionately located on the southwest side of the caldera floor. The inner wall of the caldera is steeply dipping: $40-60^{\circ}$ at the rim, $30-40^{\circ}$ on the upper half of the wall, becoming gentle toward the caldera floor. Thick talus that has possibly slumped down from the caldera wall was observed by the diving surveys, providing a reasonable explanation for the variation in dip (Naka et al., 1995). The relief of the caldera ranges from 500 to $900 \mathrm{~m}$, and the caldera rim has a relatively lower relief in the south, as shown in Fig. 2, although no large valley indicating largescale erosion is observed on either the inner or outer walls. The bathymetry map shown in Fig. 2 was created during the KR05-11 cruise of JAMSTEC.

The MCS line KR0413-1 was planned so as to pass over the Myojin Knoll caldera approximately from north to the south. The line runs over the northern rim of the caldera, approximately $1 \mathrm{~km}$ east of the central cone on the flat caldera floor and over the low-relief topography in the south of the caldera. Although the central cone is located off the MCS line, it is clearly visible on the MCS profile (Fig. 3). This cone is a kind of pseudo-structure called a "sideswipe".

\section{Data Processing and Seismic Units}

The MCS data was processed using applied geometrical spreading compensation, predictive deconvolution, DMO, velocity analysis, multiple attenuation by radon filter, NMO correction, CDP stacking, post-stack time migration, band pass filter, and post-stack depth migration. Although this volcanic area is generally characterized as 


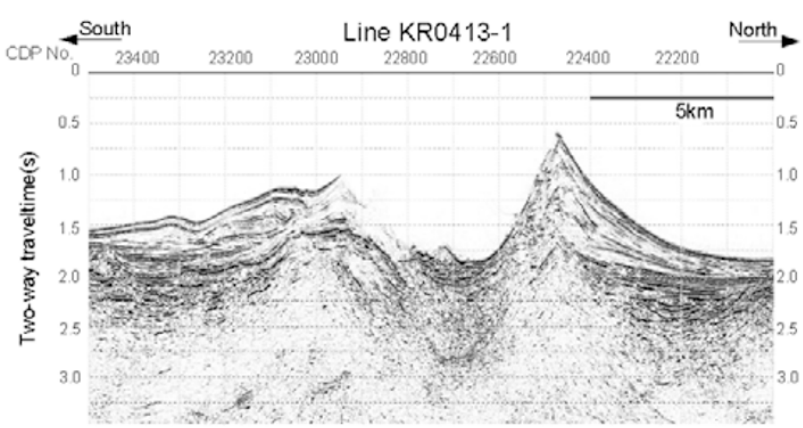

(a) Time migrated section

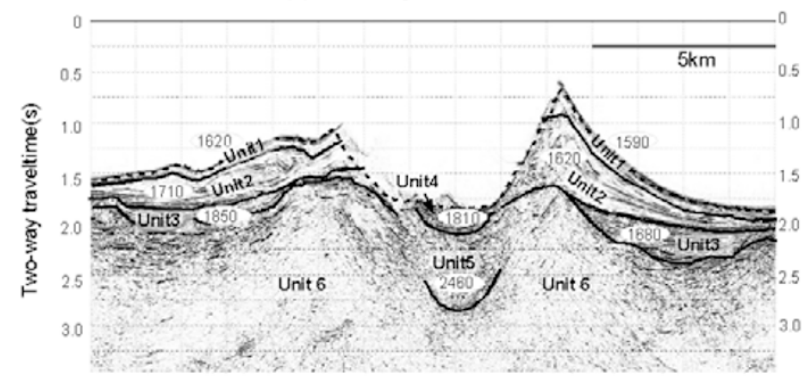

Fig. 3. Time-migrated MCS profile of Line KR0413-1 (a) and seismic units (b). Solid lines represent the boundaries of seismic units and a broken line shows the seafloor observed from the bathymetry survey. Averaged interval velocities are indicated within the units.

one of the less reflective areas, we obtained clear reflections in the caldera wall as well as beneath the caldera floor (Fig. 3(a)). In order to obtain the precise velocity structure of the caldera, we conducted a detailed velocity analysis by picking time-velocity pairs along continuous clear reflections every $62.5 \mathrm{~m}$ at places assessed to be tectonically important. The DMO correction was applied during the velocity analysis in order to suppress velocity estimation errors caused by dipping structures.

Using the stacking velocities, we conducted post-stack time migration (Fig. 3(a)) and divided the resulting migration section into seismic units (Fig. 3(b)) based on the technique of seismic stratigraphy (Vail et al., 1977). We also referred to the previous seismic interpretation by $\mathrm{Mu}-$ rakami (1997) for determining the seismic units. Poststack depth migration was also applied using the interval velocities (Fig. 4) in order to create a MCS depth section (Fig. 5(a)). In the processing of depth migration, we used velocity information obtained during a previous seismic refraction survey (Kodaira et al., 2005) that had been carried out along the same line as the MCS survey, at a depth where it is impossible to determine the precise velocity by means of a MCS velocity analysis. The characteristics of each seismic unit are as follows:

Seismic unit 1.

Unit 1 is the shallowest unit and is characterized by subparallel internal reflections with a relatively weak amplitude and somewhat transparent seismic facies. It is approximately $200 \mathrm{~m}$ thick at the northern caldera rim, becoming gradually thinner outwards from the rim. The interval velocity of this unit is $1500-1700 \mathrm{~m} / \mathrm{s}$.

Seismic unit 2.

Unit 2 also shows somewhat transparent seismic facies,

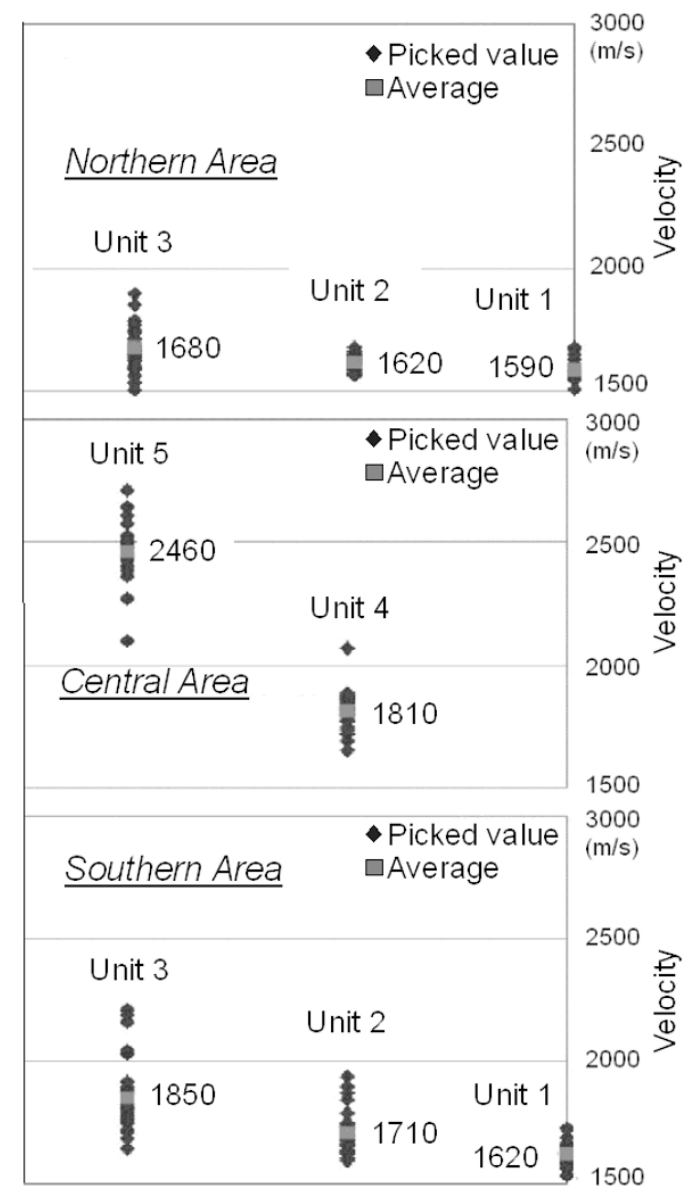

Fig. 4. $P$-wave velocities of seismic units. Interval velocities from velocity analysis of MCS reflection data are calculated to each seismic unit.

although a few strong amplitude reflections are visible. Those reflections have relatively less continuity. This unit reaches a thickness of more than $600 \mathrm{~m}$ at the northern caldera rim and also becomes gradually thinner outward from the rim. In the southern area, wavy reflections with onlap geometry are clearly visible, suggesting deformation by possible gravitational sliding. The interval velocity ranges from 1600 to $1900 \mathrm{~m} / \mathrm{s}$ within the unit.

Seismic unit 3.

This unit is characterized by well-stratified internal reflections with a high amplitude, showing limited distribution only in the depressions of the volcanic basement (the acoustic basement). It has a maximum thickness of approximately $300 \mathrm{~m}$ in the northern area. The average interval velocity is $1680 \mathrm{~m} / \mathrm{s}$ in the north and $1850 \mathrm{~m} / \mathrm{s}$ in the south. Seismic unit 4.

The shallowest seismic unit below the caldera floor is defined as seismic unit 4, where relatively stratified inner reflections are visible. Its thickness reaches $200 \mathrm{~m}$ and the average interval velocity is $1810 \mathrm{~m} / \mathrm{s}$.

Seismic unit 5.

Seismic unit 5, immediately beneath unit 4, shows chaotic seismic facies. A downwarping reflector with high amplitude is clearly observed at $2.5-2.8 \mathrm{~s}$ in the two-waytraveltime. Beneath unit 5, the seismic facies characterization is almost transparent. The depth of the reflector is ap- 


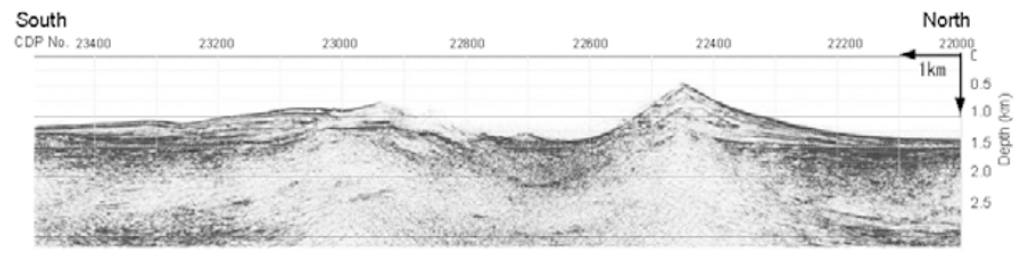

(a) Post-stack depth migrated section.

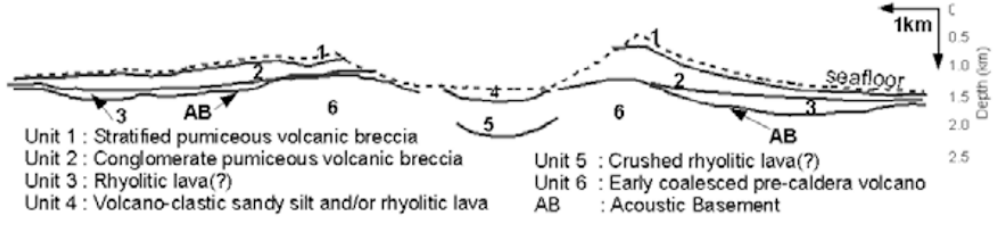

(b) Seismic units and lithology.

Fig. 5. Subsurface structure of Myojin Knoll caldera. Vertical exaggeration is one for (a) the MCS depth profile and (b) the geological cross-section with seismic units.

proximately $2.2 \mathrm{~km}$ below sea level and approximately 800 $\mathrm{m}$ below the caldera floor. The interval velocity is $2460 \mathrm{~m} / \mathrm{s}$ on average.

Seismic unit 6.

The acoustic basement is defined as a continuous strong amplitude reflector at the bottom of unit 3 and partly at the bottom of unit 2; we call a seismic unit below the acoustic basement "seismic unit 6". This unit represents the socalled volcanic basement.

\section{Lithological Correlation of Seismic Units with Surface Geology and Well Data}

Here we present the lithological correlation of the seismic units with the seafloor geology and drilling results. More than ten diving surveys were conducted by the manned submersible Shinkai 2000 of JAMSTEC at the Myojin Knoll. Previous authors (e.g., Naka et al., 1995; Murakami, 1997; Fiske et al., 2001) have summarized all of the earlier survey results and created geological cross sections of the Myojin Knoll. One example is shown in Fig. 6. In addition, the Ocean Drilling Project (ODP) at site 788, during which the eastern footwall of the Sumisu back-arc rift was drilled (Taylor et al., 1992), was located approximately $130 \mathrm{~km}$ south of the Myojin Knoll. Pumiceous deposits with a thickness of more than 200 were recognized at the site (Fig. 7), the source area of which is considered to be the submarine calderas on the present volcanic front of the northern Izu-Ogasawara Arc (Nishimura et al., 1991). Tani et al. (2007) recently suggested that the thick pumice deposits originated at the Sumisu volcano. In this chapter, we compare the seismic units with the lithology recognized from the seafloor observations (Naka et al., 1995; Fiske et al., 2001) and the drilling (Taylor et al., 1992).

\subsection{Seismic unit 1 (stratified pumiceous volcanic brec-} cia)

Stratified pumiceous volcanic breccia has been observed at the shallowest part of the Myojin Knoll caldera, which corresponds to seismic unit 1 . Its thickness was shown to be approximately $200 \mathrm{~m}$ in dives \#696/734 and approximately $200 \mathrm{~m}$ in dives \#893/1111 (Fig. 6). The sub-parallel seismic reflection pattern of the seismic unit 1 can explain the obser-

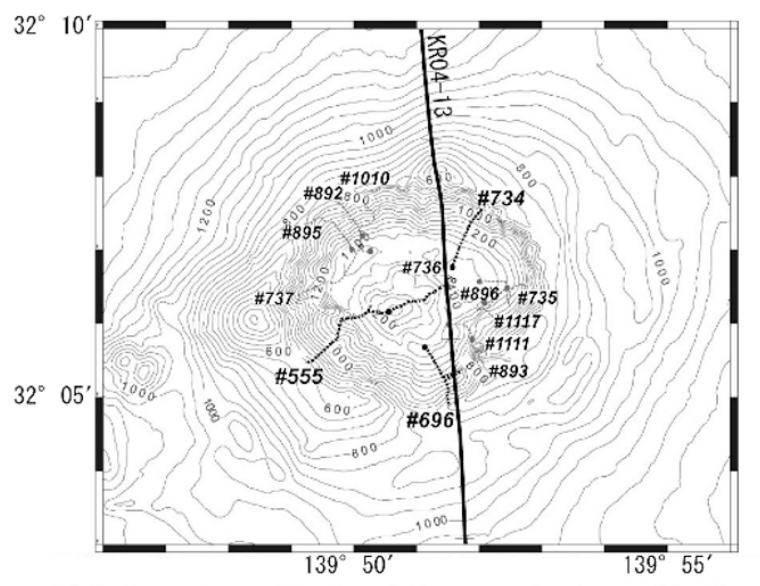

(a) Bathymetry and tracks of 13 manned submersible dives

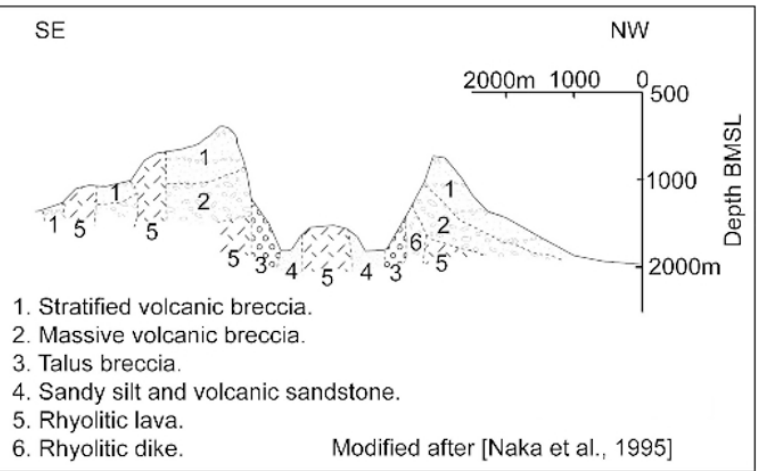

(b) Geological profile of Myojin Knoll caldera

Fig. 6. Lithology of Myojin Knoll caldera estimated from seafloor observations. Survey tracks of the manned submersible dives conducted within the caldera are drawn in (a). Based on the dives, a possible lithological section along the MCS line is shown in (b).

vation rationally. The interval velocity of the unit is nearly consistent with that of the pumiceous pyroclastic deposits obtained from the drilling (Fig. 7). We therefore correlated seismic unit 1 to the stratified pumiceous volcanic breccia. 


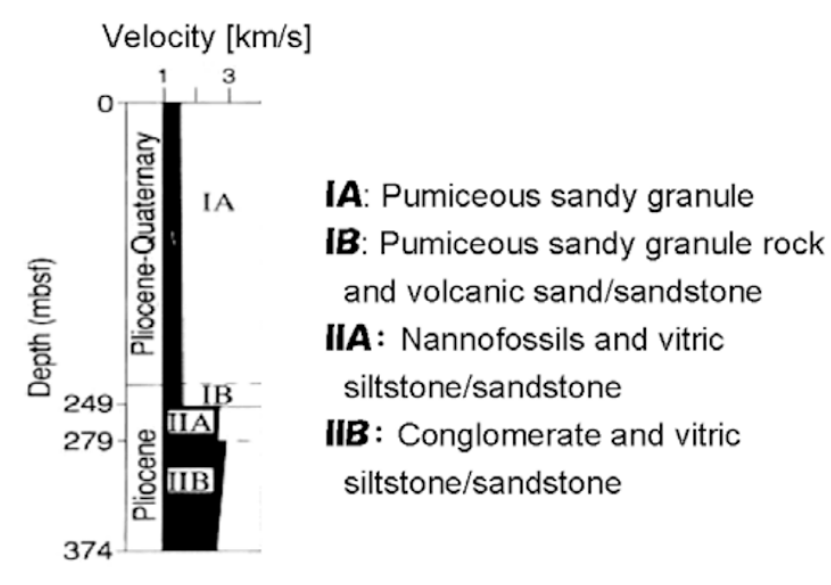

Fig. 7. Lithological column of ODP site 788.

\subsection{Seismic unit 2 (conglomerate pumiceous volcanic breccia)}

Conglomerate pumiceous volcanic breccia was recognized immediately beneath the stratified pumiceous volcanic breccia. Its thickness was shown to be less than $100 \mathrm{~m}$ in dive \#696 and greater than $200 \mathrm{~m}$ in dive \#734 (Fig. 6). We then correlated the conglomerate pumiceous volcanic breccia to seismic unit 2. Although the sub-parallel seismic pattern may not explain the conglomerate lithofacies consistently, the interval velocity of seismic unit 2 never conflicts with that of the conglomerate pumiceous volcanic breccia.

\subsection{Seismic unit 3 (rhyolite lava flow)}

Although seismic unit 3 has limited distribution, we could correlate this unit to the rhyolite lava flow, at the southern caldera wall, which is shown in figure 6 of Fiske et al. (2001). The well-stratified seismic pattern supports the lithofacies, although the interval velocity appears to be a little smaller than that of lava flow.

\subsection{Seismic unit 4 (volcano-clastic sandy silt and/or rhyolite lava)}

Based on the diving surveys, this seismic unit is inferred to be sandy silt that mainly consists of volcano-clastics (Naka et al., 1995) and/or rhyolite lava that forms a partly exposed cryptodome (figure 9 in Fiske et al., 2001). The average interval velocity of seismic unit 4 would be more consistent to the lithology of the former than that of the latter. The relatively stratified seismic reflection pattern can explain both lithofacies.

\subsection{Seismic unit 5 (fractured rhyolite)}

Seismic unit 5 has no outcrops and no drilling data to be correlated. The interval velocity of this unit is significantly greater than that of seismic units 3 and 4, whereas it appears to be inversely smaller than that of massive rhyolite or the volcanic basement. If we can assume unit 5 to be a part of the volcanic basement from its tectonic geometry, we could interpret that this unit consists of a sort of fractured rhyolite lithofacies that had originally composed the precaldera volcano, as mentioned below.

\subsection{Seismic unit 6 (pre-caldera stratovolcano edifice)}

Unit 6 , the volcanic basement, is considered to be correlated to the massive rhyolite reported in the geological map (figures 5 and 6) of Fiske et al. (2001). The unit can therefore be interpreted as a pre-caldera stratovolcano edifice.

\section{Discussion}

Based on the structural interpretation of the detailed velocity analysis of MCS data, it can be concluded that the Myojin Knoll caldera wall is mainly composed of thick pumiceous volcanic breccia. Its total thickness exceeds $800 \mathrm{~m}$ in the northern area, indicating that approximately $90 \%$ of the caldera wall consists of pumiceous volcanic breccia. Our observation, the so-called pumiceous caldera wall aspect, supports the results of previous studies based on seafloor observations (e.g., Yuasa, 1995; Naka et al., 1995; Fiske et al., 2001), gravity and magnetic surveys (e.g., Murakami and Ishihara, 1985) and SCS surveys (Yuasa et al., 1991; Murakami, 1997; Yuasa and Kano, 2003). Here we discuss on the mode of formation of the Myojin Knoll caldera.

Figure 5(b) shows a schematic cross section of the Myojin Knoll without vertical exaggeration. Units 1 and 2 represent stratified and conglomerate volcanic breccia, respectively, and unit 3 is compared with a possible rhyolitic lava flow overlying the acoustic basement that is suggestive of the top of the pre-caldera volcano of the Myojin Knoll. Unit 4 can be correlated to volcano-clastic sandy silt and/or rhyolite lava associated with cryptodome. Unit 5 is interpreted to be a sort of fractured rhyolite lithofacies, which is one of the keys to understanding the mode of caldera formation.

Previous authors have discussed the mode of formation of the Myojin Knoll caldera; However, it is still controversial and three different concepts have been proposed: (1) pumiceous caldera (like a pyroclastic cone) (Yuasa, 1995); (2) collapse caldera (Fiske et al., 2001); (3) explosion caldera (in addition to the pumiceous caldera concept) (Murakami, 1997). In terms of (1), if the caldera were a pumice cone, a considerable amount of pumice should have fallen back to not only around the volcano of those days (at the present caldera wall) but also near the volcanic vent (at the present caldera floor). These pumice deposits must be observed on or beneath the present caldera floor. However, such pumice deposits have been seldom found on the caldera floor by the seafloor observations (Yuasa, 1995), and they have not been recognized beneath the present caldera floor on our seismic profile. In the case of the collapse caldera concept (2), pyroclastic deposits that are composed of chiefly pumice should be buried immediately below the present caldera floor. However, the $P$-wave velocity of unit $5(2460 \mathrm{~m} / \mathrm{s})$ is higher than that we can predict for such deposits. Thus, both concepts (1) and (2) are unable to explain our observations. In contrast, only concept (3) is able to correlate with the velocity analysis result. If the caldera was formed by an explosion, unit 5 should have been a part of pre-caldera volcano edifice of those days. In this case, unit 5 must have a relatively high velocity that is proportional to that of rhyolite lava, which should be greater than that of pumiceous pyroclastic deposits. The interval velocity of unit 5 satisfies this condition, thereby supporting concept (3).

Finally, even if the $P$-wave velocity of unit 5 can explain the explosion concept, we still have some concern about the 
velocity value because it appears to be a little smaller than that of massive rhyolite of the pre-caldera volcano. In the present study, we conclude that the smaller velocity was a result of deformation by magma activities that have been occurring repeatedly. The magma would move up to shallow depth (unit 5 of those days), begin volumetric expansion, and form a kind of shallow magma chamber. The magma would continue to expand, leading to an explosive eruption. After the eruption, new magma would come up from the deep and this process may have been repeated. The fractured lithofacies, having a relatively small velocity, would have been formed by such process. Here, the depth of the possible shallow magma chamber is estimated to be approximately $1.4-2.2 \mathrm{~km}$ below sea level, according to the present depth of unit 5 . We interpreted that the down-warping reflector corresponds to the base of the shallow magma chamber.

\section{Conclusion}

We investigated the structure and formation history of the Myojin Knoll based on the seismic interpretation and velocity analysis of the newly acquired MCS data. The results indicated that approximately $90 \%$ of the caldera wall is composed of pumiceous volcanic breccia. As such our results support the conclusions drawn from previous studies.

We also determined the subsurface structure beneath the caldera floor; a seismic unit of fractured rhyolite lithofacies and its bottom reflector. The interval velocity of the unit correlates with the explosion caldera concept, suggesting the possibility of the existence of a shallow magma chamber at $1.4-2.2 \mathrm{~km}$ below sea level.

Acknowledgments. We express our sincere thanks to the captains, crews, and technical staffs on R/V Kairei during the cruises of the KR04-13 and KR05-11 surveys to collect geophysical data of excellent quality. We are also grateful to the Japan Agency for Marine-Earth Science and Technology, which granted permission to publish the data. Reviews by Dr. Richard S. Fiske and an anonymous referee greatly improved the seismic interpretations and the manuscript.

\section{References}

Fiske, R. S., J. Naka, K. Iizasa, and M. Yuasa, Caldera-forming submarine pyroclastic eruption at Myojin Knoll, Izu-Bonin Arc, JAMSTEC Deep Sea Res., 11, 315-322, 1995.

Fiske, R. S., J. Naka, K. Iizasa, et al., Submarine silicic caldera at the front of the Izu-Bonin arc, Japan: Voluminous seafloor eruptions of rhyolite pumice, Geol. Soc. Am. Bull., 113, 813-824, 2001.

Honza, E. and K. Tamaki, The Bonin Arc, in The Ocean Basins and Margins, edited by A. E. M. Nairn et al., 7, 459-502, Plenum Co., New York, 1985.
Iizasa, K., R. S. Fiske, O. Ishizuka, et al., A Kuroko-type polymetallic sulfide deposit in a submarine silicic caldera, Science, 283, 975-977, 1999.

Ishihara, T. and T. Yamazaki, Gravity anomalies over the Izu-Ogasawara (Bonin) and northern Mariana Arcs, Bull. Geol. Surv. Jpn., 42, 687-701, 1991.

Kodaira, S., T. Sato, N. Takahashi, A. Ito, and Y. Kaneda, Along arc crustal variation in the Izu-Bonin arc and its implications for crustal evolution processes, AGU Fall Meeting, T44A-03, 2005.

Murakami, F., The forming mechanism of the submarine caldera on Myojin Knoll in the northern part the Izu-Ogasawara (Bonin) Arc, J. Geogr., 106, 70-86, 1997 (in Japanese with English abstract).

Murakami, F. and T. Ishihara, Submarine calderas discovered in the northern part of Ogasawara Arc, Earth Month., 7, 638-646, 1985 (in Japanese).

Naka, J., R. S. Fiske, A. Taira, F. Yamamoto, K. Iizasa, and M. Yuasa, Geology of Myojin Knoll, JAMSTEC Deep Sea Res., 11, 323-331, 1995.

Nishimura, A., K. M. Marsaglia, K. S. Rodolf, A. Colella, et al., PlioceneQuaternary submarine pumice deposits in the Sumisu Rift Area, IzuBonin Arc, Sedimentation in Volcanic Setting, SEPM Special Publ., 45, 201-208, 1991.

Suyehiro, K., N. Takahashi, Y. Ariie, Y. Yokoi, R. Hino, M. Shinohara, T. Kanazawa, N. Hirata, H. Tokuyama, and A. Taira, Continental Crust, Crustal Underplating, and Low-Q Upper Mantle Beneath an Oceanic Island Arc, Science, 272, 390-392, 1996.

Takahashi, N., S. Kodaira, and Y. Kaneda, Seismic crustal sturucture of Izu Ogasawara arc back arc system (S 12), Geol. Soc. J. Ann. Meet., S-12, 2006.

Tamura, Y. and Y. Tatsumi, Remelting of an Andesitic Crust as a Possible Origin for Rhyolitic Magma in Oceanic Arcs, an Example from the IzuBonin Arc, J. Petrol., 43, 1029-1047, 2002.

Tani, T., R. S. Fiske, Y. Tamura, Y. Kido, J. Naka, H. Shukuno, and R. Takeuchi, Sumisu volcano, Izu-Bonin arc, Japan: site of a silicic caldera-forming eruption from a small open-ocean island, Bull. Volcanol., doi:10.1007/s00445-007-0153-2, 2007.

Taylor, B., K. Fujioka, et al., Proc. ODP, Sci. Results, 126, College Station, TX (Ocean Drilling Program), 1992.

Tsuru, T., J. -O. Park, T. No, K. Takizawa, and Y. Kaneda, Cruise report of 2004 seismic reflection surveys in Izu-Ogasawara arc, JAMSTEC R\&D, 2, 1-12, 2005.

Vail, P. R., R. M. Jr. Mitchum, R. G. Todd, J. M. Widmier, S.III Thompson, J. B. Sangree, J. N. Bubb, and W. G Hatleid, Seismic stratigraphy and global changes of sea level, Memoir 26, AAPG, Tulsa, 49-212, 1977.

Whitman, A. G. and R. S. J. Sparks, Pumice, Bull. Volcanol., 48, 209-223, 1986.

Yuasa, M., Myojin Knoll, Izu-Ogasawara Arc: Submersible study of submarine pumice volcano, Bull. Volcanol. Soc. Jpn., 40, 277-384, 1995 (in Japanese with English abstract).

Yuasa, M. and K. Kano, Submarine silicic calderas on the northern Shichito-Iwojima Ridge, Izu-Ogasawara (Bonin) Arc, Western Pacific, Geophys. Monogr., 140, 231-243, 2003.

Yuasa, M., F. Murakami, E. Saito, and K. Watanabe, Submarine topography of seamounts on the volcanic front of the Izu-Ogasawara (Bonin) Arc, Bull. Geol. Surv. Jpn., 42, 702-743, 1991.

T. Tsuru (e-mail: tetsuro_tsuru@cosmo-oil.co.jp), A. Okuda, T. No, Y. Kaneda, and K. Tamaki 